\title{
Essential oils from Vitex trifolia as an effective repellent for Aedes aegypti
}

\author{
NI LUH ARPIWI", I KETUT MUKSIN, ENIEK KRISWIYANTI \\ Department of Biology, Faculty of Mathematics and Natural Sciences, Universitas Udayana. Jl. Raya Kampus Unud No. 9, Jimbaran, Badung 80361, \\ Bali, Indonesia. Tel./fax.: +62-361-701954, ^email: arpiwi@unud.ac
}

Manuscript received: 2 September 2020. Revision accepted: 29 September 2020.

\begin{abstract}
Arpiwi NL, Muksin IK, Kriswiyanti E. 2020. Essential oils from Vitex trifolia as an effective repellent for Aedes aegypti. Biodiversitas 21: 4536-4544. Vitex trifolia is a shrub or small tree grown wild from family Verbenaceae commonly found in the sandy shore habitat of the tropicals and sub-tropical countries. This research aims to measure the essential oils yield of $V$. trifolia leaves, to investigate the secretory cells of the leaf, and to measure repellent activity of the essential oils against Aedes aegypti. Leaves and soil samples were taken from Panjer, Sanur, and Sidakarya Villages of Denpasar, Bali Indonesia. Oil was extracted from fresh leaf samples using steam distillation. The essential oils were analyzed for its constituents using Gas Chromatography-Mass Spectrometry. The leaf cross-sections were prepared using paraffin embedding method and stained with safranin. The essential oils of $V$. trifolia at different concentrations $(0,2,3,4,5,6 \% \mathrm{w} / \mathrm{w})$ were formulated into lotions. The yield of essential oils was significantly different from the three locations. The main constituent of the oil was cis-ocimene. The essential oil yield was positively correlated with the sand content. The secretory structures of the leaf were idioblast and glandular trichome. Lotions formulated with the essential oils were soft, not greasy, and not sticky upon application to the skin and non-irritant. Lotions with 5 and $6 \%$ essential oils gave 100\% protection for 3 hours from Ae. aegypti.
\end{abstract}

Keywords: Essential oils, idioblast, repellent, glandular trichome, Vitex trifolia

\section{INTRODUCTION}

The genus Vitex comprises more than 270 species distributed worldwide (Laxmikant 2012) contains many useful active constituents (Devika 2017). The genus is commonly used as traditional medicines for several ailments as well as complementary medicines by Asian folks. Among the genus, Vitex agnus-castus and $V$. negundo are well known for their ethnopharmacological properties, especially as an antibacterial. The two species grow in riverbanks and beaches in the Mediterranean region, Southern Europe, and in Central Asia (Rani and Sharma 2013). Vitex trifolia is a shrub or small tree grown wild from family Verbenaceae commonly found in sandy shore habitat of the tropicals and sub-tropical countries including India, Sri Lanka, China, the Philippines, Indonesia, North Australia, New Caledonia, and French Polynesia (Laxmikant 2012).

The habitus of $V$. trifolia is low, wide branches dense shrub of fewer than $5 \mathrm{~m}$ in height. The leaf color is dark green with simple and trifoliate leaves (Thenmozhi et al.2011). The leaflets are oblong or oblong-elliptical shapes with a length of 4-7 cm. The adaxial side of the leaf is smooth and shiny while the abaxial side is covered with sparse grey hairs. The aromatic soft leaves smell pungent after crushing (Rani and Sharma 2013). The flowers are white and violet is borne in terminal as an inflorescence with the length of $5-10 \mathrm{~cm}$ oblong panicles. The fruit is round shape (Chan et al. 2016; Laxmikant 2012).

There are numerous factors influencing the essential oil accumulation in the plants, such as soil types and soil texture, temperature, percentage of organic matter in the soil, altitude (Yavaria et al. 2010), climates, geographic origin, and genetics. Sometimes it is difficult to determine a single factor that influences essential oils yield since the factors are interrelated (Dhifi et al. 2016). In Vitex trifolia, the yield of essential oils even varied between the seasons. Higher yield is obtained during spring and autumn as a response of plants to stress conditions and protection to abrupt changes in weather conditions. On the other hand the decrease in essential oils production during summer and winter due to alteration of biosynthesis pathway of the plant (Dehsheikh et al. 2019).

The main constituents of the essential oils from $V$. trifolia are monoterpenes and sesquiterpenes, namely $1 \mathrm{R}-\alpha-$ pinene, ocimene, 3-carene, toluene, p-ethyl-, eucalyptol, and 3-methoxy-5-methylphenol (Devi and Singh 2014). In another study, caryophyllene and eucalyptol are the main constituents of the oil V. trifolia, which account for $38 \%$ and $26 \%$ respectively (Thomas et al. 2019). Constituents of the essential oils is also influenced by season of the year due to changes in the biosynthesis pathway. Environmental stresses, such as high temperature during summer and low temperature during winter have changed some constituents into the oxidases (Dehsheikh et al. 2019).

Essential oils from $V$. trifolia can repel mosquitos, therefore it can protect the human skin from landing or bitting (Tawatsin et al. 2006). A mosquito is a vector of many infectious diseases such as malaria, chikungunya, dengue, and Japanese encephalitis. No vaccine has been found for these mosquito-transmitted diseases (Chandrasekaran et al. 2019), therefore, controlling the vector needs to be pursued to prevent transmission of diseases (Jing and Wang 2019). One attempt to do this is 
by applying repellent onto the skin. Synthetic chemical repellent DEET (N-diethyl-3-methylbenzamide) is effective to control mosquito bites but it uses raises some health risks. Therefore, the use of plant-based insect repellent is a safe alternative (Diaz 2016).

The effectiveness of a natural anti-mosquito lotion depends on the concentration of the essential oils and of the type of species used (Uniyal et al. 2016; Arpiwi et al. 2020). The concentration of lotion containing $10 \%$ of essential oils from $V$ trifolia is more effective against three mosquito species, namely Anopheles dirus, Culex quinquefasciatus, and Ae. albopictus whereas it is less effective against Ae. aegypti (Tawatsin et al. 2006).

The adaxial surface of $V$. trifolia leaf is smooth, even with thick wall epidermis and thin cuticle layer. While the abaxial surface is uneven, with narrow cylindrical epidermal cells and covered by dense non-glandular trichomes (Thenmozhi et al. 2011). Glandular trichomes are also present in $V$. trifolia and trichome is one of morphological leaf characters of Verbenaceae (Munsif 2007).

Glandular trichomes are epidermal hairs that modified into structure for synthesis and secretion of plant secondary metabolites including terpenoid essential oils which are frequently found in leaves and stems (Lange et al. 2013). There are two types of glandular trichomes, namely peltate and capitate, which differ from each other in the number of basal, stalk, and apical cells (Guo et al. 2013). Peltate glandular trichome is characterized by a short stalk (usually one cell) and large secretory apical cells, whereas capitate glandular trichomes have variable sizes and generally have longer stalk and smaller secretory apical cells (Huchelmann et al. 2017).

The aims of the present study were to measure the essential oils yield of $V$. trifolia leaves, to investigate the secretory cells of the leaf, to measure repellent activity of the lotions containing essential oils from $V$. trifolia against Ae. aegypti.

\section{MATERIALS AND METHODS}

\section{Oil extraction}

Oil was extracted from fresh leave samples using steam distillation according to the method by Arpiwi et al. (2020). Leaf samples were taken from 3 locations/villages in Denpasar, Bali, Indonesia, namely Sidakarya, Sanur, and Panjer Villages (Figure 1). Briefly, $5 \mathrm{~kg}$ of fresh leaves was placed in the sample tank and closed tightly. The boiler was filled with a half-full with water and the condenser was equipped with water inlet and outlet. Extraction was conducted for 4 hours at water boiling temperature. The mixture of essential oils and hydrosol was collected in the separator. The essential oils were filtered using a filter paper.

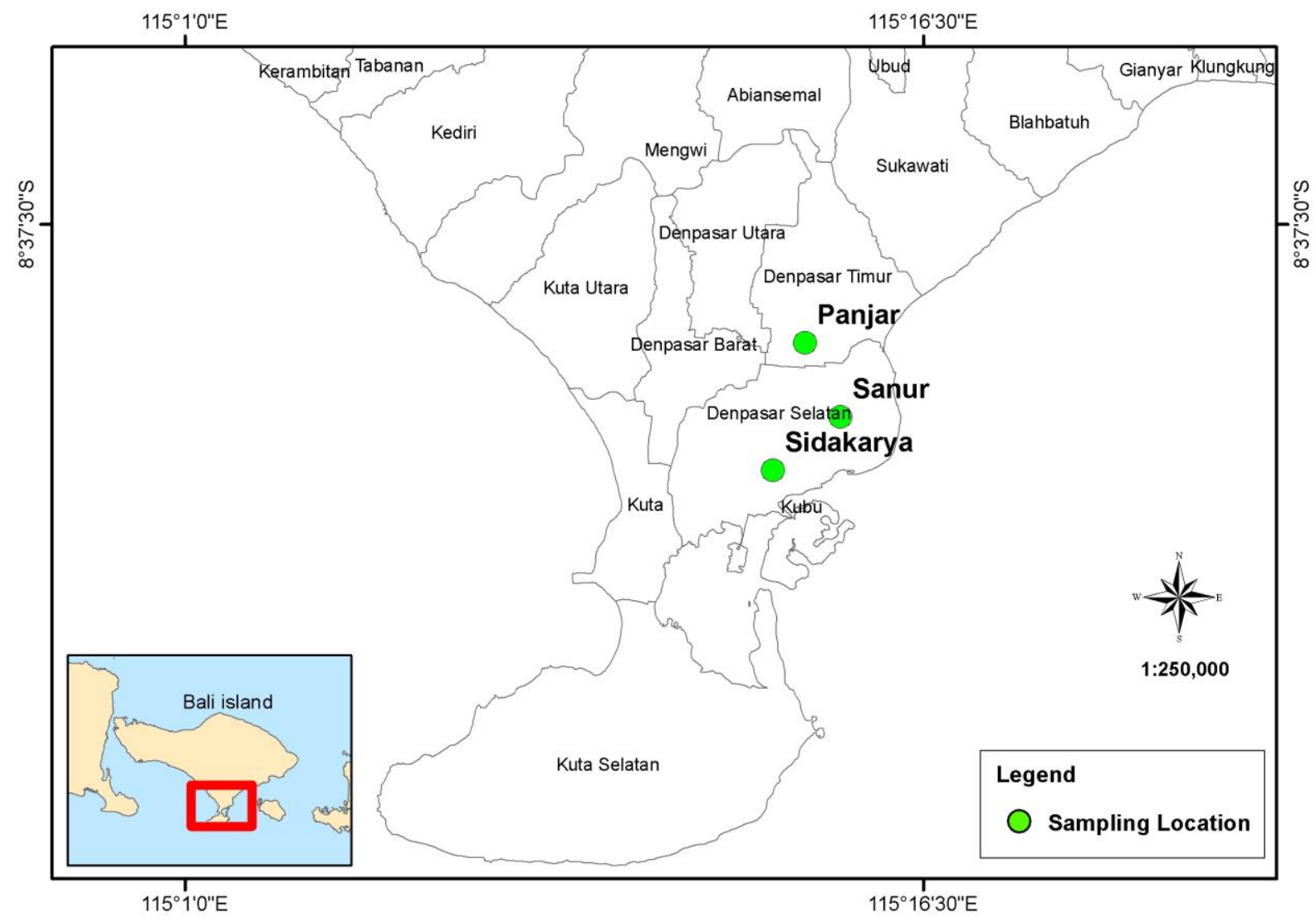

Figure 1. Study area for leaves and soil samplings from Panjer, Sidakarya, and Sanur Villages of Denpasar, Bali, Indonesia 


\section{Analysis of chemical constituents of the essential oils}

The essential oils were analyzed for its constituents using Gas Chromatography-Mass Spectrometry (GC-MS, Shimadzu-QP2010 Ultra) assay. Oil sample $(20 \mu \mathrm{L})$ was diluted using $5 \mathrm{~mL}$ absolute ethanol and then filtered using Whatman no 1 filter paper. An aliquot of $1 \mu \mathrm{L}$ was injected into the column (DB-5 MS 122-0132) with a length of 30 meters and a diameter of $0.22 \mu \mathrm{m}$. Injector temperature was $250^{\circ} \mathrm{C}$ and helium was used as a carrier gas with flow rate 3 $\mathrm{mL} /$ minute. The chemical constituents of the essential oils were identified by comparing peaks with the library.

\section{Soil analysis}

Soil samples (1 kg each) were taken from the same locations as leaf sampling, namely from Sidakarya, Sanur, Panjer of Denpasar, Bali, Indonesia (Figure 1). Soils were analyzed for $\mathrm{pH}$, electric conductivity, the content of $\mathrm{C}$ organic, total nitrogen $(\mathrm{N})$, available phosphorus $(\mathrm{P})$, available potassium $(\mathrm{K})$, content of water, sand, silt, and clay. Soil was suspended in water with soil to water ratio of $1: 2.5$ and $\mathrm{pH}$ of the suspension were measured using a $\mathrm{pH}$ meter. Electric conductivity (EC) was measured at $25^{\circ} \mathrm{C}$ Carbon (C) organic content was measured using Walkley \& Black method (Walkley and Black 1964) and total nitrogen was by Kjeldhall methods. Available $\mathrm{P}$ and $\mathrm{K}$ were determined by Bray 1 method (Bray and Kurzt 1945). Water content was measured based on field capacity using gravimetry method. Soil texture was determined by pipette method.

\section{Microscopic evaluation of the leaf}

Fully developed fresh leaf samples were harvested at the $5^{\text {th }}$ node from a shoot tip with triplicate from each location. The leaf was cross-sectioned and fixed using $10 \%$ Neutral Buffer Formalin (NBF) solution for 24 hours. Tissues then dehydrated using a tissue processor (Tissue Tek II, Model RX-II B, Sakura Seiki Co, Lid). Dehydration began with $10 \%$ NBF solution for 2 hours and then alcohol $70 \%$ for 2 hours, absolute alcohol 3 times for 2 hours each, followed by two times in toluol for 3 hours each and finally in liquid paraffin for 3 hours. Leaf tissue was embedded in liquid paraffin and then sliced in the lamina and midrib using a microtome with thickness of $4 \mu \mathrm{m}$. The sectioned tissue was placed into an object-glass and then stained with $1 \%$ aqueous safranin. The slide was closed with a cover glass and sealed with Canada balsam. The slice was cleaned with absolute alcohol and then xylol three times each. The leaf structure of the lamina and midrib was observed under a microscope and photographs were taken using an Optilab camera. The thickness of leaf tissues was measured using Image Raster 3.

Preparation, sensorial and quality analysis of the lotions Lotions were prepared based on a formula in Table 1 following a method by Arpiwi et al. (2020) with modification in the ingredients used. Lotions contained oil and aqueous phases and united by emulsifiers. The oil and aqueous phases were heated at $70^{\circ} \mathrm{C}$ in different containers. The oil phase consisted of virgin coconut oil (VCO), cetyl alcohol, stearic acid and dimethicone while aqueous phase consisted of glycerin, triethanolamine, nipagin, and distilled water. The aqueous phase was added to the oil phase slowly while stirring to mix thoroughly to form a lotion base. The temperature of the lotion base was down to $40^{\circ} \mathrm{C}$ and then essential oils from $V$. trifolia was added at 0 , $2,3,4,5$, and $6 \%$. The lotion was mix gently to homogenous mixture.

Sensorial analysis of the lotions was assessed for color, odor, sensitivity and consistency according to the method by Yadav et al. (2014). The color of the lotion was observed visually and the odor was smelled. Sensitivity was assessed to 20 human volunteers (10 males and 10 females) aged from 20 to 40 years and body weight from 50 to $70 \mathrm{~kg}$. Each volunteer was given 6 lotions (F0, F1, F2, F3, F4, and F5) and applied once each day. Lotion (1 gram) was applied behind the ears and elbow crease before night sleeping for 6 hours. Observation was conducted the next morning for any feeling of itchiness, signs of swelling, and skin rush. Consistency of the lotion was measured on softness, greasiness, and stickiness. The lotion must be easily spread and soften upon application which indicates uniform consistency. The quality of the lotion including $\mathrm{pH}$, viscosity, and homogeneity were measured according to Arpiwi et al. (2020) and it was compared to the Indonesian National Standard (SNI 16-4399-1996).

\section{Repellent activity of the lotions}

The repellent activity of the lotions was measured under laboratory conditions (Phasomkusolsil and Soonwera 2010). Twenty-five females starve mosquitos were placed in $20 \times 20 \times 20 \mathrm{~cm}$ cage covered with perforated cloth. The treatments were control + (a commercial anti-mosquito lotion), control-(lotion base) and lotion with different concentrations of $V$. trifolia essential oils $(\mathrm{F} 1=2 \%, \mathrm{~F} 2=$ $3 \%, \mathrm{~F} 3=4 \%, \mathrm{~F} 4=5 \%$ and F5 $=6 \%)$. Lotion $(1 \mathrm{~mL})$ was applied to the human hand where the right hand as a control and the left hand as treatments. The right hand was applied with basis lotion and left hand with anti-mosquito lotion. Right hand was inserted into the cage for 5 minutes every hour for a total period of six hours. The left hand was inserted into the cage soon after right hand. The number of mosquito landing or biting the hand was counted. Repellent activity was measured using the following formula by Wathoni et al. (2018).

$$
\text { Protection ability }(\%)=\frac{\Sigma(C-T)}{\Sigma C} \times 100
$$

Where; C: mosquito perch on control hand, T: mosquito perch on treated hand.

\section{Data analysis}

Essential oils content, mosquito repellent activity, quality of lotions, and soil properties were analyzed using One Way Anova with SPSS at significance level 5\%. The presence of any significant differences followed by Post Hoc analysis using Duncan. The correlation between essential oils yield and soil properties was analyzed using Pearson at 0.05 and 0.01 levels of significances. 


\section{RESULTS AND DISCUSSION}

\section{Essential oils yield}

The yield of essential oils and climate data from each location is presented in Table 1. The yield of essential oils varied significantly $(\mathrm{P}<0.05)$ among growth locations of the plants. The highest oil yield was obtained from Sidakarya $(0.0627 \% \mathrm{w} / \mathrm{w})$ while the lowest was from Panjer (0.0147\% w/w).

The yield of essential oils from fresh leaf samples in the present study was lower than another study in Iran with 0.10 to $0.22 \%$ oil yield varies seasonally (Dahsheikh et al. 2019). Growth location of the plant influenced the essential oil yield. The climate data of each location showed that during 2019 the mean of minimal and maximal temperatures ranged from 25.82 to $27.34^{\circ} \mathrm{C}$, mean of minimal and maximal humidity ranged from 81.11 to $83.14 \%$, and mean of rainfall ranged from 3.08 to 3.14 $\mathrm{mm} /$ year. Since temperature, relative humidity, and rainfall were quite similar among locations it was likely soil properties of each location might contribute to different yields of essential oils.

\section{Chemical constituents of the essential oils from Vitex trifolia}

The constituents of essential oils from V. trifolia were identified using GC-MS (Figure 2). There were 5 peaks in the chromatogram with very close retention time from one another, which ranged from 4.09 to 5.107 minutes. The 5 peaks were identified as constituents of the essential oils with different retention times and percent area (Table 2). The main constituents were cis-ocimene (44.57\%), this was followed by alpha Thujene (25.63\%), cyclopentene,3isopropenyl-5,5-dimethyl (18.19\%), $\alpha$-pinene $(6.38 \%)$, and $\beta$-pinene $(5.22 \%)$.

There were 5 chemical constituents in the essential oils from $V$. trifolia and these were much lower than other studies. For example, Thomas et al. (2019) find 16 compounds where caryophyllene and $\alpha$-Eucalyptol are the major which constitutes from $38.36 \%$ and $25.72 \%$ respectively. Chandrasekaran et al. (2018) find 89 compounds in the essential oils from $V$. trifolia with eucalyptol, sabinene, and caryophyllene are the main constituent represents for $16.35 \%, 9.44 \%$, and $8.91 \%$ respectively. The difference in the essential oil constituents probably due to internal, external factors and their interactions. For example, the maturity of plant concern, genetics, soil type, climate, and geographic origin (Figueiredo et al. 2008; Dhifi et al. 2016).

Table 2. Chemical constituents of essential oils from Vitex trifolia

\begin{tabular}{lll}
\hline Compounds & $\begin{array}{l}\text { Retention } \\
\text { time (min.) }\end{array}$ & $\begin{array}{l}\text { Area } \\
(\boldsymbol{\%})\end{array}$ \\
\hline$\alpha$-Pinene & 4.09 & 6.38 \\
$\alpha$-Thujene & 4.261 & 25.63 \\
cis-Ocimene & 4.383 & 44.57 \\
Cyclopentene,3-isopropenyl-5,5-dimethyl & 4.711 & 18.19 \\
$\beta$-Pinene & 5.107 & 5.22 \\
\hline
\end{tabular}

Table 1. Detail locations of leaf and soil samplings, essential oils yield, and climate data during 2019

\begin{tabular}{lcccccc}
\hline Location & Latitude & Longitude & Oil yield & $\begin{array}{c}\text { Mean of minimal and } \\
\text { maximal temperatures }\left({ }^{\circ} \mathbf{C}\right)\end{array}$ & $\begin{array}{c}\text { Mean of minimal and } \\
\text { maximal humidity }(\%)\end{array}$ & $\begin{array}{c}\text { Rainfall } \\
(\mathbf{m m} / \text { year })\end{array}$ \\
\hline Panjer & $8^{\circ} 39^{\prime} 59^{\prime \prime} \mathrm{S}$ & $115^{\circ} 14^{\prime} 11^{\prime \prime} \mathrm{E}$ & $0.0147 \pm 0.001 \mathrm{a}$ & $25.89-27.28$ & $81.86-82.89$ & 3.13 \\
Sidakarya & $8^{\circ} 42^{\prime} 39^{\prime \prime} \mathrm{S}$ & $115^{\circ} 13^{\prime} 21^{\prime \prime} \mathrm{E}$ & $0.0627 \pm 0.010 \mathrm{c}$ & $25.82-27.34$ & $82.10-83.13$ & 3.14 \\
Sanur & $8^{\circ} 41^{\prime} 32^{\prime \prime} \mathrm{S}$ & $115^{\circ} 14^{\prime} 46^{\prime \prime} \mathrm{E}$ & $0.0473 \pm 0.004 \mathrm{~b}$ & $25.88-27.28$ & $81.11-83.14$ & 3.08 \\
\hline
\end{tabular}

Values of oil yields were mean \pm standard deviation (SD) from triplicates. Values in the same colomn followed by different letters were significantly different at $\mathrm{P}<0.05$.

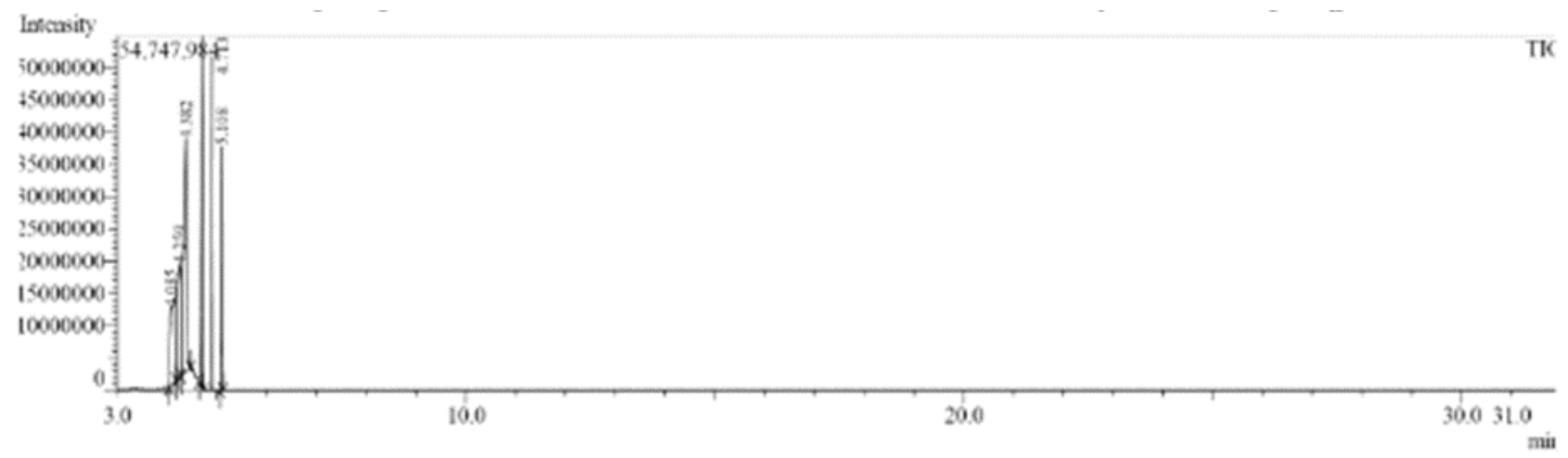

Figure 2. Gas Chromatography-Mass Spectrometry (GC-MS) profile of the essential oils from Vitex trifolia 


\section{Soil properties}

Soil properties from each sampling location are presented in Table 3. All locations had similar $\mathrm{pH}$, electric conductivity, and available potassium. The content of $\mathrm{C}$ organic in Panjer and Sanur was 2.99 and $2.56 \%$ respectively, and in Sidakarya was $1.6 \%$. Total nitrogen content was $0.13 \%$ both in Panjer and Sanur and $0.06 \%$ in Sidakarya. The available phosphorus was very high both in Panjer and Sanur and high in Sidakarya. Water content (field capacity) was $37.02 \%$ in Panjer, $26.01 \%$ in Sanur, and $27.62 \%$ in Sidakarya. Soil texture in Panjer was loam, while in Sanur and Sidakarya were loamy sand respectively.

The essential oils yield was negatively correlated with electric conductivity, $\mathrm{C}$ organic, available $\mathrm{P}$ and $\mathrm{K}$, water content, content of silt, and clay. This means that an increase in essential oils yield is accompanied by a decrease in those soil properties. In other plant species, such as Ziziphora clinopodioides, the essential oil yield is negatively correlated with EC and $\mathrm{pH}$ (Amiri et al. 2019). The only highly positive correlation on oil yield was with sand content with Pearson correlation values of 0.927 . This indicated that the yield of essential oils is greatly influenced by the sand content of the soil. The soil sample from Sidakarya contained $78.74 \%$ sand and V. trifolia from this location contained the highest oil $(0.0627 \% \mathrm{w} / \mathrm{w})$. Similar result is also reported in other plant species of Thymus migricus where the essential oil yield is positively correlated with sand content in the soil, whereas clay and silt contents are negatively correlated (Yavaria et al. 2010).

\section{Microscopic evaluation of leaf}

The cross-section of lamina is presented in Figure 3. The leaf thickness ranged from $160.18 \pm 1.11 \mu \mathrm{m}$ to 225.97 $\pm 1.27 \mu \mathrm{m}$. The adaxial epidermis was $16.9 \pm 0.91$ $25.59 \pm 0.85 \mu \mathrm{m}$ thick, layered with thin cuticle and had sparse single-celled non-glandular trichomes. A double layer hypodermis of 51.46 $\pm 1.53-56.92 \pm 1.21 \mu \mathrm{m}$ thick was beneath the epidermis, where the second layer was interrupted in places by 4-18 palisade cells. The mesophyll consisted of 4-5 layers cylindrical palisade cells. Idioblasts were observed in the mesophyll which was large and isodiametric. Spongy parenchyma was found beneath the palisade. The abaxial epidermis was thinner than the adaxial and had dense glandular and non-glandular trichomes. These refer to glandular and non-glandular hairs (Dogan et al. 2008). Idioblast is an internal secretory cell which is bigger and differ in shape from neighboring cells and contains terpenes in Lantana camara of the Verbenaceae family (Zabele et al. 2005; Passos et al. 2009). In terms of cell size, it was not the case of idioblast in the present study where it was hardly distinguished from the variable sizes of neighboring cells. Some neighboring cells were smaller, some bigger and some nearly the same sized. According to Muliyah et al. (2018), idioblast can be distinguished by the cell content since idioblast is morphologically similar to neighboring cells. In the present study, idioblast stained red color more intense than neighboring cells, possibly indicating the cell content.

Table 3. Soil properties at different locations

\begin{tabular}{|c|c|c|c|c|c|c|c|c|c|c|c|}
\hline \multirow[b]{2}{*}{ Location } & \multirow[b]{2}{*}{$\mathbf{p H}$} & \multirow{2}{*}{$\begin{array}{c}\text { EC } \\
(\mathbf{m m h o s} / \mathbf{c m})\end{array}$} & \multirow[b]{2}{*}{ C organic } & \multirow[b]{2}{*}{$N$ total } & \multirow{2}{*}{$\begin{array}{c}\text { Available } \\
\mathbf{P}\end{array}$} & \multirow{2}{*}{$\begin{array}{c}\text { Available } \\
\mathbf{K}\end{array}$} & \multirow{2}{*}{$\begin{array}{c}\text { Water } \\
\text { content } \\
(\%)\end{array}$} & \multicolumn{3}{|c|}{ Content of (\%) } & \multirow[b]{2}{*}{ Texture } \\
\hline & & & & & & & & Sand & Silt & Clay & \\
\hline Panjer & 7.7 & 0.68 & 2.99 & 0.13 & 107.95 & 216.03 & 37.02 & 42.67 & 46.49 & 10.84 & Loam \\
\hline Sidakarya & 7.7 & 0.54 & 1.6 & 0.06 & 26.48 & 171.54 & 27.62 & 78.74 & 15.74 & 5.52 & Loamy sand \\
\hline Sanur & 7.8 & 0.52 & 2.56 & 0.13 & 48.38 & 202.92 & 26.01 & 77.73 & 20.36 & 1.96 & Loamy sand \\
\hline
\end{tabular}

Note: The correlation between essential oils yield and soil properties is presented in Table 4. Some soil parameters negatively and positively correlated with oil yield at 0.05 and 0.01 levels of significances

Table 4. Correlation between essential oils yield and soil properties

\begin{tabular}{|c|c|c|c|c|c|c|c|c|c|c|c|}
\hline & $\begin{array}{l}\text { Oil yield } \\
(\% \text { w/w })\end{array}$ & $\mathbf{p H}$ & $\begin{array}{c}\text { EC } \\
(\mathrm{mmhos} / \mathrm{cm})\end{array}$ & $\begin{array}{c}\mathrm{C} \\
\text { organic } \\
(\%)\end{array}$ & $\begin{array}{c}\mathbf{N} \text { total } \\
(\%)\end{array}$ & $\begin{array}{c}\text { Available } \\
\text { P (ppm) }\end{array}$ & $\begin{array}{c}\text { Available } \\
\text { K }(\%)\end{array}$ & $\begin{array}{c}\text { Water } \\
\text { content } \\
(\%)\end{array}$ & $\begin{array}{c}\text { Sand } \\
(\%)\end{array}$ & $\begin{array}{l}\text { Silt } \\
(\%)\end{array}$ & $\begin{array}{l}\text { Clay } \\
(\%)\end{array}$ \\
\hline Oil yield (\% w/w) & 1 & 0.276 & $-0.881 * *$ & $-0.890 * *$ & $-0.751 *$ & $-0.963 * *$ & $-0.883 * *$ & $-0.901 * *$ & $0.927 * *$ & $-0.956 * *$ & -0.695 \\
\hline $\mathrm{pH}$ & 0.276 & 1 & -0.346 & -0.700 & 0.162 & -0.271 & -0.063 & -0.410 & 0.361 & -0.307 & -0.503 \\
\hline $\mathrm{EC} \mathrm{mmhos/cm}$ & $-0.881 * *$ & -0.346 & 1 & 0.659 & 0.485 & $0.923 * *$ & 0.658 & $0.960 * *$ & $-0.974 * *$ & $0.952 * *$ & $0.915 * *$ \\
\hline C organic $(\%)$ & $-0.890 * *$ & -0.07 & 0.659 & 1 & $0.943 * *$ & $0.888 * *$ & $0.998 * *$ & $0.688 *$ & $-0.760 *$ & $0.834 * *$ & 0.387 \\
\hline $\mathrm{N}$ total $(\%)$ & $-0.751^{*}$ & 0.162 & 0.485 & $0.943 * *$ & 1 & $0.736 *$ & $0.940 * *$ & 0.465 & -0.569 & 0.661 & 0.157 \\
\hline Available P (ppm) & $-0.963 * *$ & -0.271 & $0.923 * *$ & $0.888 * *$ & $0.736 *$ & 1 & $0.884 * *$ & $0.937 * *$ & $-0.937 * *$ & $0.993 * *$ & $0.764^{*}$ \\
\hline Available K (\%) & $-0.883 * *$ & -0.063 & 0.658 & $0.998 * *$ & $0.943 * *$ & $0.884 * *$ & 1 & $0.679 *$ & $-0.754 *$ & $0.830 * *$ & 0.376 \\
\hline ntent $(\%)$ & $-0.901 * *$ & -0.41 & $0.96 * *$ & $0.688 *$ & 0.465 & $0.937 * *$ & $0.679 *$ & 1 & $-0.987 * *$ & $0.966^{* *}$ & $0.923 * *$ \\
\hline Sand & 0 & 0.3 & $* *$ & $-0.760 *$ & -0 . & -0 . & -0 . & $-0.987 * *$ & 1 & $-0.992 * *$ & $-0.888 * *$ \\
\hline Silt & $-0.956 * *$ & -0.307 & & $0.834 * *$ & & 0.99 & $0.830 * *$ & $0.966^{* *}$ & $-0.992 * *$ & 1 & $0.822 * *$ \\
\hline Clay (\%) & $-0.695^{*}$ & -0.503 & $0.915^{* *}$ & 0.387 & 0.157 & $0.764 *$ & 0.376 & $0.923 * *$ & $-0.888 * *$ & $-0.822 * *$ & 1 \\
\hline
\end{tabular}

Note: Water content was measured based on the field capacity. C: carbon, EC: electric cobductivity, K: potassium, N: nitrogen, P: phosphorous, *: Correlation is significant at the 0.05 level, **: Correlation is significant at the 0.01 level 


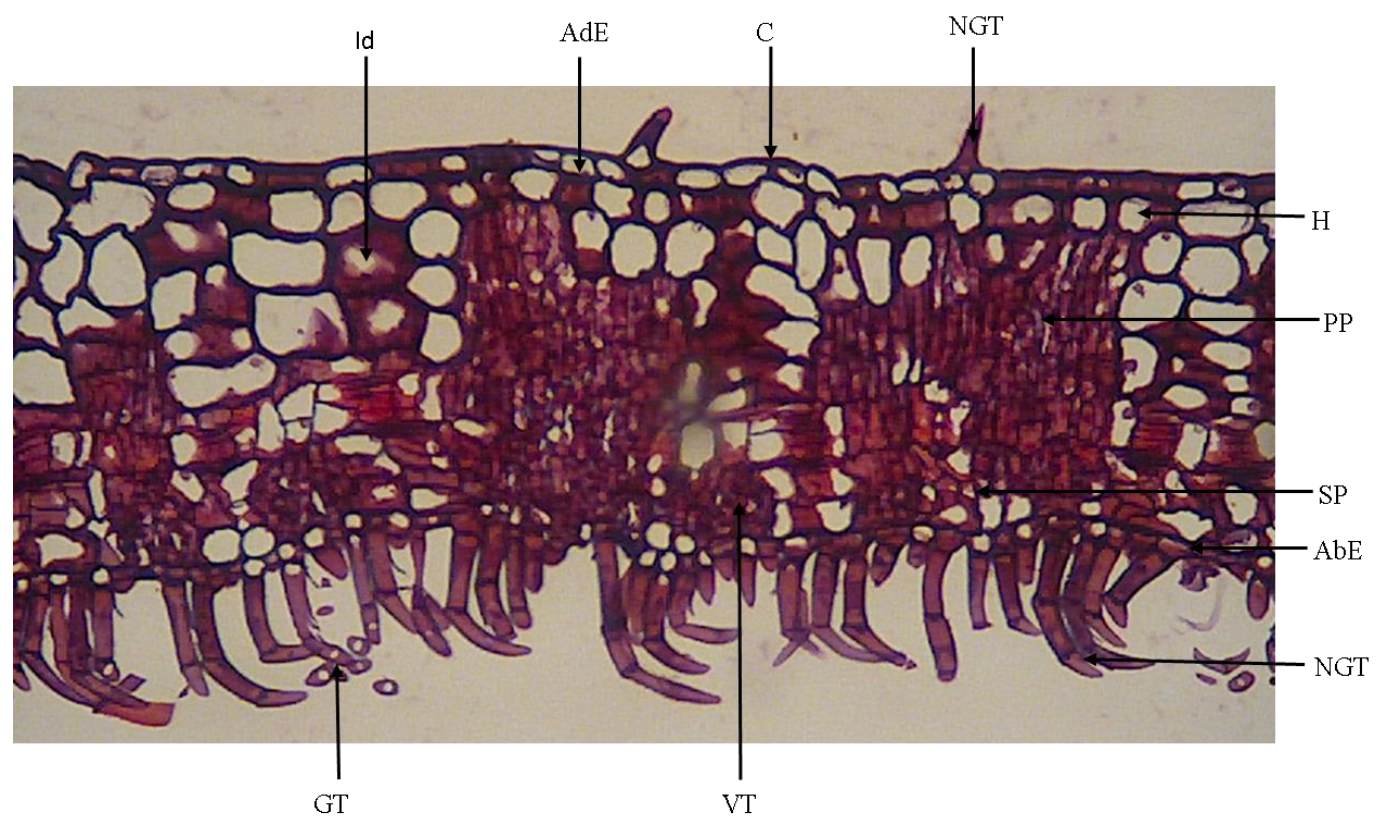

Figure 3. Cross-section of Vitex trifolia leaf via lamina. AbE: abaxial epidermis, AdE: adaxial epidermis, C: cuticle, GT: glandular trichome, H: hypodermis, I: idioblast, PP: palisade parenchyma, SP: spongy parenchyma, NGT: non-glandular trichome, VT: vascular tissue

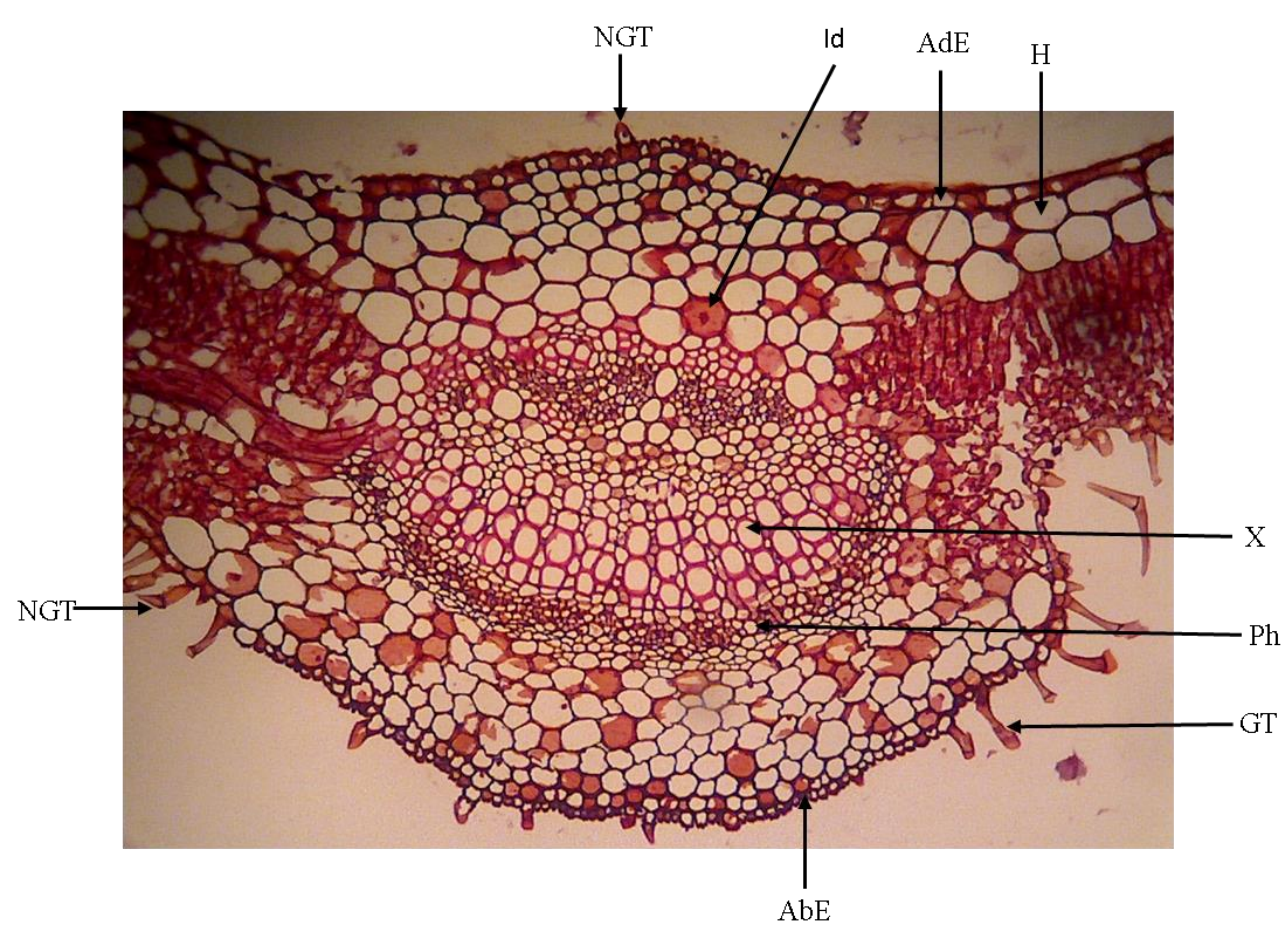

Figure 4. Cross section of Vitex trifolia leaf via midrib. $\mathrm{AbE}=$ abaxial epidermis, $\mathrm{AdE}=$ adaxial epidermis, $\mathrm{C}=$ cuticle, $\mathrm{GT}=\mathrm{glandular}$ trichome, $\mathrm{H}=$ hypodermis, $\mathrm{I}=$ idioblast, $\mathrm{Ph}=$ phloem, $\mathrm{PP}=$ palisade parenchyma, $\mathrm{SP}=$ spongy parenchyma, NGT = non-glandular trichome, $\mathrm{VT}=$ vascular tissue, $\mathrm{X}=$ xylem

Trichome is a hair-like epidermal derivate present in aerial parts of plants. There are two types of trichomes, glandular and non-glandular. Glandular trichome is a site of essential oils secretion and accumulation in many plant species (Huchelmann et al. 2017) including member of the Verbenaceae family (Combrinck et al. 2007). Nonglandular trichome in $V$. trifolia was the single-celled conical shape of the adaxial surface, and long multiple celled in the abaxial surface of the leaf. Both glandular and non-glandular trichomes play important roles in plant protection and defense against biotic and abiotic stresses, such as UV and oxidative stress, water deficit, and herbivores (Glas et al. 2012; Karabourniotis et al. 2020). 
The cross-section of midrib is presented in Figure 4. The midrib ranged from $650.29 \pm 17.27$ to $930.29 \pm 4.46 \mu \mathrm{m}$ thick and predominantly to the abaxial side of the leaf. It consists of adaxial epidermis with sparse non-glandular trichomes. Beneath the adaxial epidermis was two hypodermal layers with large rectangular, square, and isodiametric cells. The vascular system was in the median arch of midrib consists of several parallel rows of xylems and surrounded by several layers of phloem elements. Isodiametric idioblast presented in the ground tissue stained red. Abaxial epidermis covered with glandular and non-glandular trichomes with smaller and shorter than those in the lamina.

The secretory structure of $V$. trifolia leaves was internal secretory cells idioblast and external secretory cells, glandular trichome. These were found in both lamina and midrib. In other species of the Verbenaceae, such as Lantana camara, those secretory structures also exist (Passos et al. 2009; Moura et al. 2005). The secretory structures are site of essential oils biosynthesis, accumulation, and storage (Lee and Ding 2016).

\section{Sensorial analysis of the lotions}

Sensorial analysis of the lotions including color, odor, sensitivity, and consistency is presented in Table 5. The color of lotion base (F0) and lotion with $2 \%$ essential oils was white, while the color of F2, F3, F4, and F5 was yellowish-white due to the addition of essential oils from $V$. trifolia. The odor of lotion ranged from weak, mild to strong as the percentage of essential oils added increases. The lotion base had no odor since it was not added with essential oils. All lotions did not cause rush, itchy, and swell to the human volunteers, meaning that the lotion did not cause sensitivity. The lotions were soft, not greasy, and not sticky upon application to the skin indicating acceptable consistency.
Sensorial analysis of the lotions revealed that the lotion has weak, mild to strong odors of essential oils of $V$. trifolia. Lotion with $5 \%$ essential oils had a mild odor while lotion with $6 \%$ essential oils had strong odor and both had similar protection abilities. This might be of the customer preferences who might like mild or strong odors. The lotions were non-irritant and this confirmed safe for human skins. The lotions were not sticky or greasy and these give comfort to the skins. Safety, effectiveness, and pleasant during uses are prerequisites of plant-based insect repellent (Diaz et al. 2016). These prerequisites were fulfilled by the lotions formulated with essential oils from $V$. trifolia. In addition, the quality of formulated lotions met the requirement of National Indonesian Standard (SNI 164399-1996) for $\mathrm{pH}$, viscosity, and homogeneity. Composition of the lotions along with mixing techniques greatly influenced consistency and homogeneity of the lotions (Yadav et al. 2014).

The quality of the lotions including $\mathrm{pH}$, viscosity, and homogeneity were compared to the Indonesian National Standard (SNI 16-4399-1996) is presented in Table 6. The $\mathrm{pH}$ of lotions ranged from 6.41 in $\mathrm{F} 0$ to 6.87 in F5. The viscosity of the lotions ranged from 3016.66 in F0 to 2694.00 in F5 and all lotions were homogenous. These indicated that the formulated lotions fulfilled the requirements of the standard.

\section{Repellent activity of the lotions}

The repellent activity of the lotions containing essential oils from $V$. trifolia was measured as percentage of protection ability during the 6-hour experiment. Protection ability (\%) of the lotions is presented in Table 7 . There was significantly different $(\mathrm{P}<0.05)$ among formulated lotions in their protection ability.

Table 5. Sensorial analysis of the lotions

\begin{tabular}{cllcc}
\hline \multicolumn{1}{c}{ Color } & & Odor & Sensitivity & Consistency \\
\hline F0 & White & No odor & Nil & Acceptable \\
F1 & White & Weak $V$. Trifolia oil & Nil & Acceptable \\
F2 & Yellowish white & Mild $V$. Trifolia oil & Nil & Acceptable \\
F3 & Yellowish white & Mild $V$. Trifolia oil & Nil & Acceptable \\
F4 & Yellowish white & Mild $V$. Trifolia oil & Acceptable \\
F5 & Yellowish white & Strong V. Trifolia oil & Acceptable \\
\hline
\end{tabular}

Note: F0: lotion base, F1: lotion with $2 \%$ essential oils, F2: lotion with 3\% essential oils, F3: lotion with 4\% essential oils, F4: lotion with $5 \%$ essential oils, F5: lotion with $6 \%$ essential oils

Table 6. Quality of the anti-mosquito lotions

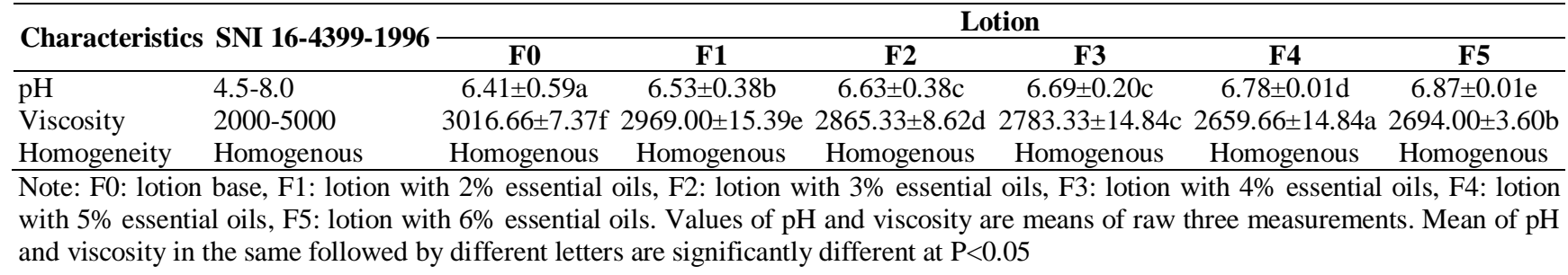


Table 7. Repellent activity of anti-mosquito lotion with different concentrations of essential oils from Vitex. trifolia at different time (hour) of observation

\begin{tabular}{lccccccc}
\hline \multirow{2}{*}{ Lotion } & \multicolumn{7}{c}{ Protection ability (\%) at different time of observation (hour) } \\
\cline { 2 - 7 } & $\mathbf{0}$ & $\mathbf{1}$ & $\mathbf{2}$ & $\mathbf{3}$ & $\mathbf{4}$ & $\mathbf{5}$ & $\mathbf{6}$ \\
\hline Control- & $40.00 \pm 0.49 \mathrm{a}$ & $31.21 \pm 0.98 \mathrm{a}$ & $29.00 \pm 0.95 \mathrm{a}$ & $27.23 \pm 1.19 \mathrm{a}$ & $24.88 \pm 1.20 \mathrm{a}$ & $20.51 \pm 1.86 \mathrm{a}$ & $18.71 \pm 0.73 \mathrm{a}$ \\
Control + & $95.78 \pm 0.52 \mathrm{~d}$ & $92.14 \pm 1.05 \mathrm{~d}$ & $85.31 \pm 1.45 \mathrm{~d}$ & $62.77 \pm 1.80 \mathrm{c}$ & $51.62 \pm 0.87 \mathrm{c}$ & $44.86 \pm 1.87 \mathrm{~b}$ & $35.18 \pm 1.33 \mathrm{~b}$ \\
F1 & $61.48 \pm 1.15 \mathrm{~b}$ & $56.20 \pm 0.65 \mathrm{~b}$ & $52.22 \pm 1.30 \mathrm{~b}$ & $50.41 \pm 0.69 \mathrm{~b}$ & $48.85 \pm 0.82 \mathrm{~b}$ & $46.15 \pm 1.75 \mathrm{~b}$ & $45.77 \pm 0.78 \mathrm{c}$ \\
F2 & $69.83 \pm 0.68 \mathrm{c}$ & $68.79 \pm 0.84 \mathrm{c}$ & $65.52 \pm 0.96 \mathrm{c}$ & $61.6 \pm 0.62 \mathrm{c}$ & $59.95 \pm 1.09 \mathrm{~d}$ & $57.47 \pm 0.89 \mathrm{c}$ & $55.55 \pm 0.59 \mathrm{~d}$ \\
F3 & $100.00 \pm 0.00 \mathrm{e}$ & $100.00 \pm 0.00 \mathrm{e}$ & $100.00 \pm 0.00 \mathrm{e}$ & $99.74 \pm 0.51 \mathrm{~d}$ & $92.15 \pm 1.18 \mathrm{e}$ & $85.74 \pm 0.74 \mathrm{~d}$ & $80.77 \pm 0.40 \mathrm{e}$ \\
F4 & $100.00 \pm 0.00 \mathrm{e}$ & $100.00 \pm 0.00 \mathrm{e}$ & $100.00 \pm 0.00 \mathrm{e}$ & $100.00 \pm 0.00 \mathrm{~d}$ & $95.55 \pm 0.92 \mathrm{f}$ & $90.62 \pm 0.75 \mathrm{e}$ & $81.17 \pm 0.87 \mathrm{e}$ \\
F5 & $100.00 \pm 0.00 \mathrm{e}$ & $100.00 \pm 0.00 \mathrm{e}$ & $100.00 \pm 0.00 \mathrm{e}$ & $100.00 \pm 0.00 \mathrm{~d}$ & $96.97 \pm 0.79 \mathrm{f}$ & $85.79 \pm 0.75 \mathrm{~d}$ & $85.16 \pm 0.63 \mathrm{f}$ \\
\hline
\end{tabular}

Note: Control-: lotion base, control +: commercial anti-mosquito lotion, F1-F5: lotion with essential oils from V. trifolia at 2, 3, 4, 5, and $6 \%$ respectively. Values are mean \pm standard deviation (SD) with 4 replications. Mean of protection ability in the same column followed by different letters are significantly different at $\mathrm{P}<0.05$

The highest protection ability was achieved by lotion with $5 \%$ and $6 \%$ essential oils while the lowest was by control-(lotion base). Lotion base had $40 \%$ protection ability at $0 \mathrm{~h}$ and it decreased gradually over time and finally was $18.71 \%$ at $6 \mathrm{~h}$. Commercial anti-mosquito lotion (control + ) had $95.78 \%$ protection at $0 \mathrm{~h}$ and it decreased every hour and at 6 hours, it was 35.18\%. Lotions with 5 and $6 \%$ essential oils gave $100 \%$ protection for 3 hours from Ae. aegypti. The protection remained high which was $80.77 \%$ to $85.16 \%$ during six hours of experiment.

The protection ability of formulated lotions was much higher and longer compared to commercial anti-mosquito lotion contains DEET (Tabel 6). These results indicated that essential oils from $V$. trifolia at low concentration (5$6 \%$ ) incorporated into lotions were an effective repellent for Ae. aegypti. The repellent activity is due to the synergy effect of chemical constituents presented in the essential oils (Nerio et al. 2010). In other research, repellent activity is measured as protection time, which is the time from application of essential oils until two successive bites observe. By using this method the protection time of lotion with $10 \%$ essential oils from $V$. trifolia is 1.8 hours against Ae. aegypti, 8 hours against both Ae. albopictus and Anopheles dirus, and 7.5 hours against $A n$. quinquefasciatus. Ae.aegypti is more aggressive than other species tested, therefore the species has shorter protection time than others (Tawatsin et al., 2006). Therefore, the protection ability of lotions containing essential oils from $V$. trifolia needs to be tested using other diseases-vector mosquito species, such as An. dirus and $A n$. quinquefasciatus. Nonetheless, essential oils from $V$. trifolia possessed good repellent activity against $A e$. aegypti, where at concentrations of 5-6\% in lotions gave $100 \%$ protection for 3 hours and it remained high $(81.17 \%$ and $85.16 \%$ ) at $6 \mathrm{~h}$.

Chemical constituents of essential oils that have strong repellent activity are monoterpenes and sesquiterpenes (Nerio et al. 2010). The essential oils components in $V$. trifolia were $\alpha$-Pinene, $\alpha$-Thujene, cis-ocimene, and $\beta$ Pinene and according to Tan et al. (2015), these compounds belong to monoterpenes group.

In conclusion, the yield of essential oils from $V$. trifolia ranged from $0.0147 \pm 0.001$ to $0.0627 \pm 0.010 \% \mathrm{w} / \mathrm{w}$. The constituents of the oil were cis-ocimene, $\alpha$-Thujene, Cyclopentene,3-isopropenyl-5,5-dimethyl, $\alpha$-Pinene, and $\beta$-Pinene. The oil yield was positively correlated with the sand content of the soil. The secretory structure of the leaf was idioblast and glandular trichome. Lotions formulated with essential oils from $V$. trifolia were soft, not greasy and not sticky upon application and non-irritant. Lotions with 5 and 6\% essential oils gave 100\% protection for 3 hours from Ae. aegypti and the protection remained high during six hours of experiment.

\section{ACKNOWLEDGEMENTS}

We would like to thank Ministry Education and Culture Republic of Indonesia for funding this research via DIPA PNBP 2020, Udayana University, Bali, Indonesia with research scheme Penelitian Unggulan Udayana.

\section{REFERENCES}

Arpiwi NL, Muksin IK, Kartini NL. 2020. Essential oils from Cymbopogon nardus and repellent activity against Aedes aegypti. Biodiversitas 21 (8): 3873-3878.

Amiri F, Gholipouri A, Kheirkhah M, Mirjalili MH. 2019. Study on ethnobotany and the effect of ecological factor on the yield of essential oils of Ziziphora clinopodioides Lam. (case study: Yazd Province). J Med Plants By-Products 2: 189-199.

Bray RH, Kurtz LT. 1945. Determination of total, organic, and available forms of phosphorus in soils. Soil Science 59: 39-45.

Chandrasekaran T, Thyagarajan A, Santhakumari PG, Pillai AKB, Krishnan UM. 2019. Larvicidal activity of essential oils from Vitex negundo and Vitex trifolia on dengue vector mosquito Aedes aegypti. Rev Soc Bras Med Trop 52: e20180459. DOI: 10.1590/0037-86820459-2018.

Chan EWC, Baba S, Chan SHT, Kainuma M, Tangah J. 2016. Medicinal plants of sandy shores: a short review on Vitex trifolia L. and Ipomoea pes-caprae (L.) R.Br. Indian J Nat Prod Resour 7 (2): 107 115.

Combrinck S, Du Plooy GW, McCrindle RI, Botha BM. 2007. Morphology and histochemistry of the glandular trichomes of Lippia scaberrima (Verbenaceae), Ann Bot 99 (6): 1111-1119.

Dehsheikh AB, Sourestani MM, Dehsheikh PB, Vitalini S, Iriti M, Mottaghipisheh J. 2019. A comparative study of essential oils constituents and phenolic compounds of Arabian Lilac (Vitex trifolia var. Purpurea): an evidence of season effects. Foods 8: 52. DOI: $10.3390 /$ foods 8020052 . 
Devi WR, Singh CB. 2014. Chemical composition, anti-dermatophytic activity, antioxidant and total phenolic content within the leaves essential oils of Vitex trifolia. Intl J Phytocosm Nat Ingred 1: 1-5. DOI: $10.15171 /$ ijpni.2014.05

Devika R. 2017. A Review on genus Vitex-a novel medicinal plant. Int J Pharma Res Health Sci 5 (6): 1904-1908.

Dhifi W, Bellili S, Jazi S, Bahloul N, Mnif W. 2016, Essential oils chemical characterization and investigation of some biological activities: a critical review. Medicines 25: 1-16.

Diaz JH. 2016. Chemical and plant-based insect repellents: efficacy, safety, and toxicity. Wilderness Environ Med 27: 153-163.

Dogan Y, Ay G, Kozuharova E. 2008. A study on the anatomical characteristics of Vitex agnus-castus (Verbenaceae). Phytologia Balcanica 14 (1): 97-101.

Figueiredo AC, Barroso JG, Pedro LG, Scheffer JJC. 2008. Factors affecting secondary metabolite production in plants: volatile components and essential oils. Flavour and Fragrance Journal 23: 213-226.

Glas JJ, Schimmel BC, Alba JM, Escobar-Bravo R, Schuurink RC, Kan MR. 2012. Plant glandular trichomes as targets for breeding or engineering of resistance to herbivores. Intl J Mol Sci 13: 1707717103.

Guo J, Yuan Y, Liu Z, Zhu J. 2013. Development and structure of internal glands and external glandular trichomes in Pogostemon cablin. PLoS ONE 8 (10): e77862. DOI: 10.1371/journal.pone.0077862.

Hulchelmann A, Bountry M, Hachez C. 2017. Plant glandular trichomes natural cell factories of high biotechnological interest. Plant Physiol 175: 6-22.

Jing Q, Ming W. 2019. Review dengue epidemiology. Global Health J 3 (2): $37-45$

Karabourniotis G, Liakopoulos G, Nikolopoulos D, Bresta P. 2020 Protective and defensive roles of non-glandular trichomes agains multiple stresses: structure-function coordination. J For Res 3: 1-12.

Lange BM, Glenn W, Turner GW. 2013. Review article terpenoid biosynthesis in trichomes-current status and future opportunities. Plant Biotechnol J 11: 2-22.

Laxmikant K. 2012. Vitex trifolia Linn. (Verbenaceae): a review on pharmacological and biological effects, isolated and known potential phytoconstituents of therapeutic importance. J Res Pharm Sci 3 (3): 441-445.

Lee YL, Ding P. 2016. Production of essential oils in plant: ontogeny, secretory structures and seasonal variations. Pertanika J Scholarly Res Rev 2 (1): 1-10.

Moura MZD, Isaias RMDS, Soares GLG. 2005. Ontogenies of internal secretory cells in leaves of Lantana camara (Verbenaceae). Bot $\mathrm{J}$ Linn Soc 148: 427-431.

Muliyah E, Sulistijorini, Sulistyaningsih YC, Rafi M. 2018. Tetracera scandens as a medicinal plant: secretory structures, histochemistry, and antibacterial activity. J Trop Life Sci 8 (1): 68-74

Munsif S, Khan MA, Ahmad M, Zafar M, Shah GM, Shaheen N. 2007. Leaf epidermal anatomy as an aid to the identification of genera Lantana, Verbena and Vitex of family Verbenaceae from Pakistan. J Agric Soc Sci 3 (2): 43-46.
Nerio LS, Verbel JO, Stashenko E. 2010. Repellent activity of essential oils: a review. Bioresour Technol 101: 372-378.

Passos JL, Meira RMSA, Barbosa LCA. 2009. Foliar anatomy of the species Lantana camara and L. radula (verbenaceae). Planta Daninha 27 (4): 689-700.

Phasomkusolsil S, Soonwera M. 2010. Insect repellent activity of medicinal plant oils against Aedes aegypti (Linn.), Anopheles minimus (Theobald) and Culex quinquefasciatus Say based on protection time and biting rate. Southeast Asian J Trop Med Public Health 41 (4): 831-40.

Rani A, Sharma A. 2013. The genus Vitex: a review. Pharmacogn Rev 7 (14): 188-198.

Standard Nasional Indonesia (SNI) 16-4399-1996. Sediaan tabir surya [Indonesian].

Tahri D, Elhouiti F, Ouinten M, Yousfi M. 2019. Distribution modeling, soil properties, and variation in essential oils chemical composition of Rhanterium adpressum Coss. \& Dur. Eur J Ecol 5 (2): 111-117.

Tan LTH, Lee LH, Yin WF, Chan CK, 2015. Review Article Traditional uses, phytochemistry, and bioactivities of Cananga odorata (YlangYlang). Evid-Based Compl Altern Med 2015: 896314. DOI: $10.1155 / 2015 / 896314$.

Tawatsin A, Asavadachanukorn P, Thavara U, Wongsinkongman P, Bansidhi J, Boonruad T, Chavalittumrong, P, Soonthornchareonnon N, Komalamisra N, Mulla MS. 2006. Repellency of essential oils extracted from plants in Thailand against four mosquito vectors (Diptera: Culicidae) and oviposition deterrent effects against Aedes aegypti (Diptera: Culicidae). Southeast Asian J Trop Med Public Health 37 (5): 915-931.

Thenmozhi S, Sundaram RS, Kumar JP, Bihari CG. 2011. Pharmacognostical and phytochemical investigation on leaves of Vitex trifolia Linn. J Pharma Res 4 (4): 1259-1262.

Thomas RP, Ramachandran A, Paul J, Mohan M. 2019. Essential oils studies of the genus Vitex L. (Verbenaceae). Intl J Adv Res 7 (5): 568-574.

Uniyal A, Tikar SN, Mendki MJ, Singh R, Shukla SV, Agrawal OP, Veer V, Sukumaran D. 2016. Behavioral response of Aedes aegypti mosquito towards essential oils using olfactometer. J. ArthropodBorne Dis 10 (3): 372-382.

Walkley A, Black IA. 1934. An examination of Degtjareff method for determining soil organic matter, and proposed modification of the chromic acid titration method. Soil Sci 37: 29-38.

Wathoni N, Sriwidodo, Sofian FF, Narsa AC, Mutiara AN. 2018. Repellent activity of essential oils from Cananga odorata Lamk. and Cymbopogon nardus L. on corn starch-based thixogel. J Young Pharm 10: s118-s123.

Yadav NP, Rai VK, Mishra N. Sinha, DU. Bawankule, Pal A, Tripathi AK, Chanotiya CS. 2014. A novel approach for development and characterization of effective mosquito repellent cream formulation containing citronella oil. BioMed Res Intl 2014: 786084. DOI: $10.1155 / 2014 / 786084$

Yavaria A, Nazeria V, Sefidkon F, Hassania ME. 2010. Influence of some environmental factors on the essential oil variability of Thymus migricus. Nat Prod Commun 5 (6): 943-948. 